Volume 11, Nomor 1, Mei 2019, pp 115 - 126 Copyright (C) 2017 Jurnal Akuntansi Maranatha, Program Studi Akuntansi, Fakultas Ekonomi,Universitas Kristen Maranatha. ISSN 2085-8698 | e-ISSN 2598-4977. http://journal.maranatha.edu

\title{
Efektivitas Komite Audit Dan Kualitas Audit Terhadap Earnings Management Pada Perusahaan Terdaftar Di BEI
}

\author{
Fany \\ Fakultas Bisnis dan Ekonomika Program Studi Akuntansi- Univ. Surabaya \\ (Jl. Raya Kalirungkut, Kota Surabaya) \\ fany090496@gmail.com \\ Yie Ke Feliana \\ Fakultas Bisnis dan Ekonomika Program Studi Akuntansi- Univ. Surabaya \\ (Jl. Raya Kalirungkut, Kota Surabaya) \\ yiekefeliana@staff.ubaya.ac.id
}

\begin{abstract}
This study aims to examine the effectiveness of the audit committee and audit quality on earning management. This research is quantitative by using multiple linear regression. In addition, this study uses 496 samples of non-financial sector business entities listed on the Indonesia Stock Exchange period 2014-2015. Practice Earning management will be proxied with discretionary accrual. The audit committee will be proxied with the number of audit committees, independent audit committees, audit committee expertise, and frequency of meetings of the audit committee. At audit quality will be proxied with auditor's reputation, industry specialist auditor, and audit tenure.

The results show that audit committees and auditor reputation have an affective role in decreasing earning management. The audit committee and industry specialization auditors have no effect on earning management. Similarly, the audit committee and long audit period also no effect on earning management. On the audit committee, audit tenure, and industry specialist auditors have no effect on earning management. However, the auditor's reputation has a negative effect on earning management.
\end{abstract}

Keywords: Audit Committee, Audit Quality, Earning Management.

\section{Pendahuluan}

Skandal laporan keuangan di beberapa perusahaan (seperti Enron, WorldCom, dan lain-lain) telah memicu krisis kepercayaan tentang keandalan informasi keuangan dan memiliki efek yang buruk bagi stakeholder(Zgarni et al., 2016).Pada tahun 2001, kasus Enron telah terlibat dalam rangkaian transaksi keuangan yang kompleks dimana terdapat penipuan akuntansi yang sistematis, terlembaga, dan direncanakan secara kreatif.Akibatnya, laporan keuangan terkesan sangat bagus di mata investor (Liputan6, 2014). Selain itu, di Indonesia sendiri kasus terbaru tahun 2017 dalam dunia audit, yaitu Kantor Akuntan Publik mitra Ernst and Young's (EY) di Indonesia, yakni KAP Purwantono, Suherman dan Surja membayar denda 
senilai US\$ 1 juta (sekitar Rp 13,3 miliar) kepada regulator Amerika Serikat, akibat kegagalan dalam melakukan audit laporan keuangan kliennya (Tempo, 2017). Kasus itu merupakan insiden terbaru dalam kantor akuntan publik, sehingga menimbulkan keprihatinan bagi kantor akuntan publik dalam menjalankan praktek usahanya di negara berkembang sesuai dengan kode etik.

Menurut Garg (2007) menyatakan bahwa corporate governance telah menarik banyak perhatian dari regulator, akademisi, dan praktisi karena corporate governance dapat meningkatkan kepercayaan investor dan meningkatkan kesehatan ekonomi perusahaan yang terdaftar. Selain itu, menurut Leventis dan Dimitropoulos (2012), tata kelola perusahaan telah menarik banyak perhatian selama dekade terakhir dari para riset dan pelaku pasar yang disebabkan karena runtuhnya perusahaan yang dihormati seperti Enron, WorldCom, dan Arthur Andersen yang menimbulkan banyak kekhawatiran tentang keandalan pelaporan keuangan dan efisiensi mekanisme pemantauan yang ada. Jika dikaitkan dari kasus diatas, maka timbul pertanyaan yang relevan tentang good corporate governance dalam memastikan keuangan bahwa laporan keuangan telah disajikan sesuai dengan kondisi perusahaan kepada pihak eksternal perusahaan.

Masalah utama pada penelitian akuntansi adalah sejauh mana manajer mengubah laba yang dilaporkan untuk menguntungkan kepentingan sendiri (Beneish, 2001). Selain itu, menurut Dechow dan Skinner (2000), ketika manajer berusaha mengelola pendapatan secara oportunis, maka dapat meningkatkan kekayaan pribadi mereka sehingga manajemen laba dapat menutupi kinerja ekonomi perusahaan yang sebenarnya dan menyembunyikan informasi kepada pengunna laporan keuangan. Menurut Christiani dan Nugrahanti (2014), menyatakan bahwa timbulnya praktik earning management dikaitkan dengan teori agensi yang disebabkan adanya asimetri informasi.

Regulator dan investor sering mengkritik peran dari komite audit dan auditor eksternal tentang hasil laporan keuangan yang diaudit dimana terbukti informasi dari laporan keuangan yang disajikan dapat menyesatkan sehingga banyak terjadi skandal akuntansi (Alves, 2013). Padahal komite audit memiliki tanggung jawab untuk mengawasi proses pelaporan keuangan dalam meninjau laporan keuangan perusahaan, proses audit, dan pengendalian akuntansi internal (Klein, 2002). Selain itu, adanya kehadiran auditor eksternal juga memainkan peran penting dalam menajmin konservasi dan penerbitan kualitas pelaporan keuangan (Alzoubi, 2016).Oleh karena itu, penting untuk menyelidiki pengaruh antara komite audit dan auditor eksternal terhadap earning management dimana berpotensi mempengaruhi integritas pelaporan keuangan (Alves, 2013). Berdasarkan hasil paparan diatas, peneliti tertarik untuk melakukan penelitian lebih mendalam mengenai pengaruh antara efektivitas komite audit dan kualitas audit terhadap earning management yang berada di Indonesia.

\section{Kerangka Teoritis dan Hipotesis}

\section{Earning Management}

Menurut Scott (2015: 445), Earning Management is the choice by a manager of accounting policies, or real action, affecting earnings so as to achive some specific some specific reporterd earning objective. Pada pilihan atas accounting policies terbagi menjadi dua, yaitu kebijakan akuntansi dan discretionary accrual.Dalam kebijakan akuntansi contohnya pemilihan metode penyusutan dan kebijakan pengakuan pendapatan, sedangkan discretionary accrual, yaitu provision for credit losses, warranty cost, inventory values, dan lain-lain. Dalam 
discretionary accrual, ada istilah " accrual reverse". Menurut Scott (2015), Accrual reverse yang dimaksud yaitu apabila manajer melakukan earning upward yang jumlahnya lebih besar secara terus menerus, maka pembalikan akrual pada periode berikutnya memaksa pendapatan di masa depan akan turun sama seperti pendapatan saat ini yang dinaikkan.

\section{Komite Audit}

Menurut Zgarni et al. (2016), efektivitas komite audit diukur dengan ukuran komite audit, independen komite audit, keahlihan (expertise), dan frekuensi meeting. Terdapat beberapa studi sebelumnya yang membahas mengenai karakteristik komite audit ini. Seperti menurut Defond dan Francis (2005), komite audit yang besar, dapat mendorong dewan untuk lebih memperbaiki kualitas pelaporan keuangan. Dengan adanya komite audit yang lebih besar, maka dapat memberikan pemantauan yang efektif. Selain itu, hal yang penting mengenai efektivitas komite audit dalam melakukan pemantauan tata kelola adalah independensinya (Abbot et al., 2000; Bronson et al., 2009). Menurut Rahmat et al. (2009), komite audit yang independen maka pengambilan keputusannya lebih objektif. Kemudian, menurut Rahmat et al. (2009), komite audit yang memiliki keahlian pengetahuan dan akuntansi dapat memberikan dasar yang baik bagi anggota komite audit dalam memeriksa dan menganalisis informasi keuangan. Latar belakang pendidikan dapat menjadi karakterikstik penting dalam memastikan peran komite audit secara efektif. Selain itu, menurut Menurut Khlif dan Samaha (2016) menyatakan bahwa adanya rapat komite audit dapat memberikan bukti bahwa mekanisme tata kelola perusahaan semakin transparan. Selama rapat komite audit, permasalahan yang dihadapi dalam proses pelaporan keuangan dapat terdeteksi, namun apabila frekuensi pertemuan rendah, maka masalah tersebut dapat berlanjut dan mungkin tidak bisa terselesaikan dalam waktu singkat (Nor et al., 2010). Jadi, dapat disimpulkan ukuran komite audit yang besar, komite audit yang independen, adanya keahlian komite audit, dan frekuensi meeting yang tinggi, maka peran dari komite audit tersebut efektif.

\section{Kualitas Audit}

Menurut Taktak dan Mbarki (2014), audit eksternal merupakan mekanisme tata kelola lain yang dapat membatasi manajerial praktek discretionary. Selain itu, Menurut Lidiawati dan Asyik (2016) mengemukakan bahwa salah satu cara dalam mengontrol earning management yaitu dengan melakukan audit atas laporan keuangan sehingga audit eksternal dapat menjadi mekanisme pengendalian terhadap manajemen dalam menyajikan informasi keuangan secara akurat dan terbebas dari praktik kecurangan akuntansi. Menurut Bartov et al., (2000) menyatakan bahwa kualitas audit yang tinggi maka akan melaporakan kesalahan dan penyimpangan dan tidak mau menerima praktik akuntansi yang patut dipertanyakan. Oleh karena itu, auditor yang memiliki kualitas audit yang tinggi diharapkan dapat mendeteksi praktik manajemen laba (Becker et al., 1998).

\section{Pengembangan Hipotesis}

Menurut Klein (2002) menemukan bahwa keberadaan komite audit akan mengurangi earning management yang disebabkan karena peran komite audit dapat mencegah fraudulent financial reporting. Namun, menurut Prastiti dan Merianto (2013) menyatakan bahwa komite audit tidak memiliki pengaruh signifikan terhadap earning management. Hal ini disebabkan karena pembentukan komite audit hanya didasarkan pada pemenuhan regulasi sehingga perannya menjadi kurang efektif dalam memonitor manajemen. Pada penelitian Rusmin (2010), menyatakan bahwa auditor spesialisasi industri berpengaruh negatif terhadap earning management.Hal ini disebabkan karena bahwa auditor spesialisasi industri 
memberikan layanan audit (audit service) kepada klien sehingga menghasilkan kualitas informasi akuntansi yang tinggi (Sun dan Liu, 2012).Namun, menurut Farida dan Alfin (2014) menyatakan bahwa auditor yang memiliki keahlian, pengetahuan, dan pengalaman belum tentu objektif dan independen karena cenderung mempertahankan kliennya. Penelitian Zgarni et al. (2016) mengemukakan bahwa ada hubungan yang saling melengkapi antara efektivitas komite audit dan auditor spesialisasi industri dalam membatasi earning management. Hal ini didukung oleh penelitian Abbot dan Parker (2000) yang mengemukakan bahwa auditor spesialisasi industri cenderung untuk melaporkan kesalahan dan kecurangan sehingga memberikan kepastian tinggi bagi komite audit. Namun menurut Chen et al. (2005) mengemukakan bahwa pertemuan komite audit yang tinggi tidak memiliki pengaruh signifikan terhadap penggunaan auditor spesialis industri. Hal ini disebabkan karena pertemuan rapat yang tinggi belum mencerminkan komite audit telah menjalankan tugasnya dengan efektif.

H1: Semakin efektif komite audit dan penggunaan auditor eksternal yang terspesialis dalam industri tertentu, maka earning management menurun.

$$
\text { Menurut Rusmin }
$$

menyatakan bahwa adanya kehadiran KAP big four dan auditor spesialisasi industri dapat menurunkan manajemen laba. Hal ini disebabkan KAP Big four biasanya memiliki basis klien yang besar dan memiliki brand names yang diakui secara internasional, sehingga lebih banyak insentif untuk mempertahankan kualitas audit yang lebih tinggi. Apabila dibandingkan KAP non big four, maka lebih cenderung mempertahankan klien yang sudah ada. Penelitian sebelumnya seperti Zgarni et al. (2016) dan Alves (2013) mengemukakan bahwa efektivitas komite audit dan kualitas audit (Big Four) memiliki pengaruh negatif terhadap earning management. Hal ini disebabkan karena dengan adanya komite audit dan auditor eksternal dapat mengurangi masalah keagenan dalam mengurangi manajemen laba (Innam dan Khamoussi, 2016). Menurut Alves (2013), komite audit dan auditor eksternal merupakan bagian dari keseluruhan struktur tata kelola perusahaan. Hal ini disebabkan karena komite keduanya tidak mungkin beroperasi secara independen dalam struktur perusahaan.

H2: Semakin efektif komite audit dan penggunaan auditor eksternal big four, maka earning management menurun.

Menurut Myers et al. (2003) mengemukakan bahwa semakin tinggi audit tenure, maka akan menurunkan kualitas pendapatan sehingga dapat menjadi mislead bagi investor Namun, menurut Jackson et al. (2008), Puspitasari dan Nugrahanti (2016), serta Amijaya dan Prastiwi (2013) yang menyatakan bahwa kualitas audit (audit tenure) tidak memiliki pengaruh terhadap manajemen laba. Hal ini disebabkan karena kurangnya kemampuan auditor perusahaan dalam mengidentifikasi manajemen laba yang dilakukan oleh perusahaaan (Amijaya dan Prastiwi, 2013).Menurut Meixner and Walker (1988) dalam Zgarni et al. (2016), mengemukakan bahwa interaksi antara komite audit dan auditor eksternal dapat meningkat seiring dengan meningkatnya masa jabatan (tenure). Hal ini disebabkan karena komite audit yang lebih efektif lebih cenderung untuk mempertahankan auditor selama auditor tersebut dapat memberikan kualitas pelaporan keuangan yang tinggi.

Menurut Zgarni et al. (2016) menyatakan bahwa komite audit yang memiliki hubungan jangka panjang dengan auditor eksternal, akan menghasilkan tingkat kepercayaan dan ketergantungan yang tinggi antara auditor eksternal dengan perusahaan. Akibatnya, masa audit yang panjang akan meningkatkan earning management.

H3: Semakin efektif komite audit dan semakin panjang masa audit eksternal, maka earning management menurun. 


\section{Metode Penelitian}

\section{Jenis Penelitian}

Dalam penelitian ini, penulis menggunakan pendekatan kuantitatif atau pendekatan positivism dimana research question ini akan dirumuskan dalam bentuk hipotesis dengan tujuan untuk mengetahui pengaruh antara efektivitas komite audit dan kualitas audit terhadap earning management

\section{Populasi dan Sampel}

Objek dalam penelitian ini adalah badan usaha yang bergerak pada sektor non keuangan yang terdaftar d BEI periode 2014-2015 dengan kriteria: (1) Badan usaha yang menyajikan laporan keuangan dengan satuan mata uang rupiah, (2) Badan usaha yang menjajikan laporan keuangan denan periode akuntansi pada tahun yang berakhir 31 desember dan telah diaudit, (3) Badan usaha menyajikan annual report lengkap selama periode penelitian serta memiliki data keuangan yang mendukung variabel yang ada.

\section{Tabel 1}

\begin{tabular}{|l|c|}
\multicolumn{2}{|c|}{ Kriteria Pemilihan Sampel } \\
\hline \multicolumn{1}{|c|}{ Ketersugan } & Total \\
\hline $\begin{array}{l}\text { Populasi Badan Usaha tahun } \\
\text { 2014-2015 }\end{array}$ & 851 \\
\hline $\begin{array}{l}\text { Badan usaha yang } \\
\text { menerbitkan laporan } \\
\text { keuangan USD Dollar }\end{array}$ & $(167)$ \\
\hline $\begin{array}{l}\text { Badan usaha yang tidak } \\
\text { mempublikasikan lengkap } \\
\text { laporan keuangan }\end{array}$ & $(31)$ \\
\hline $\begin{array}{l}\text { Badan usaha yang tidak } \\
\text { tersedia data yang dibutuhkan } \\
\text { untuk menghitung variabe1 }\end{array}$ & $(140)$ \\
\hline $\begin{array}{l}\text { Jumlah tahun perusahaan } \\
\text { yang menjadi sampe1 } \\
\text { penelitian periode 2014-2015 }\end{array}$ & 513 \\
\hline
\end{tabular}

Sumber: Hasil Olahan Peneliti

\section{Teknik Pengumpulan Data}

Langkah-langkah yang dilakukan peneliti untuk mengumpulkan data adalah sebagai berikut:
1. Menentukan dan membuat daftar perusahaan sektor non keuangan yang terdaftar di BEI periode 2014-2015 menjadi populasi dalam penelitian ini. Daftar nama-nama perusahaan ini dapat diperoleh dari Fact Book.

2. Mencari annual report dan laporan keuangan perusahaan di website www.idx.co.id

3. Mencari data laporan keuangan atas perusahaan yang digunakan selama periode penelitian pada periode 2014 2015 yang mempublikasikan laporan keuangannya pada periode yang berakhir 2014-2015 dengan cara mendownload dari www.idx.co.id .

4. Mencari semua data variabel yang diperlukan dalam penelitian ini pada semua badan usaha yang lolos seleksi.

5. Menginput data-data ke dalam Microsoft Excel 2007 secara manual.

6. Memindahkan data yang telah diinput dalam Microsoft Excel 2007 ke dalam program Statistical Product and Service Solutions (SPSS) 20 untuk membantu dalam mengelola data statistik.

\section{Definisi dan Operasional Variabel}

Variabel dependen pada penelitian ini adalah earning management dengan menggunakan abnormal (discretionary) accrual dimana diukur menggunakan Modified Jones Model pada basis crosssectional sesuai dengan Dechow et al. (1995) Perhitungan menggunakan Modified Jones Model ini yaitu sebagai berikut:

a. Total accruals (TA) dapat dihitung dengan menggunakan rumus sebagai berikut:

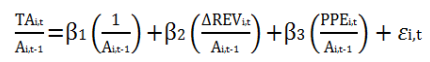

b. Abnormal (discretionary) accruals dapat dihitung dengan menggunakan rumus sebagai berikut:

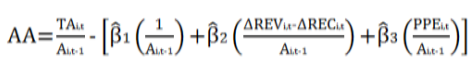

paua perusanladil 1 untuk tanlun $t$, yantg didefinisikan sebagai laba bersih dikurangi 
dengan arus kas operasi; AA adalah abnormal accruals; $\Delta \mathrm{REV}_{\mathrm{i}, \mathrm{t}}$ adalah perubahan revenue pada perusahaan i untuk tahun $\mathrm{t} ; \quad \triangle \mathrm{REC}_{\mathrm{i}, \mathrm{t}}$ adalah perubahan receivable pada perusahaan i untuk tahun $\mathrm{t}$; $\mathrm{A}_{\mathrm{i}, \mathrm{t}-1}$ adalah total aset perusahaan pada awal tahun $\mathrm{t} ; \mathrm{PPE}_{\mathrm{i}, \mathrm{t}}$ adalah aset tetap pada perusahaan i untuk tahun $\mathrm{t} ; \hat{\beta}_{1}, \hat{\beta}_{2}$, dan $\hat{\beta}_{3}$ adalah estimasi regresi dari koefisien $\beta_{1}, \beta_{2}$, dan $\beta_{3}$; dan $\varepsilon$ i,tadalaherror atau sisa regresi.

Variabel independen pada penelitian ini yaitu efektivitas komite audit dan kualitas audit. Pada variabel efektivitas komite audit diukur menggunakan ukuran komite audit (SIZEAC), proporsi komisaris independen dalam komite audit (ACIND), proporsi keahlian komite audit yang ahli di bidang akuntansi dan keuangan (ACEXPERT), dan pertemuan komite audit (ACMEET). Setelah itu variabel dari masing-masing komite audit ini ditotal menjadi SCOREAC. Pada variabel kualitas audit diukur menggunakan ukuran auditor (REPUT) yaitu bernilai 1 apabila perusahaan diaudit oleh KAP Big Four, sedangkan bernilai 0 apabila perusahaan diaudit oleh KAP Non Big Four. Selain itu, pengukuran yang lain, yaitu auditor spesialisasi industri (SPEC) dicari dengan menghitung pangsa pasar dari tiap KAP dengan menjumlah sales pada suatu badan usaha diaudit oleh KAP tersebut dibagi dengan seluruh total sales badan usaha dalam industri tersebut. Apabila perusahaan yang diaudit dengan pangsa pasar lebih dari $10 \%$ maka bernilai 1 , sedangkan apabila kurang dari $10 \%$, maka akan bernilai 0 . Selain itu, masa audit (TENURE) merupakan jumlah tahun berturut-turut bahwa klien mempertahankan perusahaan audit (KAP) tersebut.

Pada penelitian ini variabel moderasinya yaitu interaksi antara efektivitas komite audit dengan reputasi auditor (SCOREAC $\mathrm{x}$ REPUT). Nilai moderasi akan menjadi 0 , apabila perusahaan menggunakan KAP non big four. Pada variabel SCOREAC $x$ SPEC untuk menguji interaksi antara efektivitas komite audit dan auditor spesialisasi industri. Nilai moderasi akan bernilai 0, apabila perusahaan yang diaudit memiliki pangsa pasar kurang dari $10 \%$. Sedangkan variabel SCOREAC $\mathrm{x}$ TENURE untuk menguji interaksi antara efektivitas komite audit dan masa audit dengan cara mengalikan kedua variabel tersebut.

Variabel kontrol pada penelitian ini mengacu pada Zgarni et al. (2016), yaitu ukuran perusahaan (FSIZE) yang menggunakan Natural Logarithm of Total Aset; leverage (LEV) menggunakan rasio total utang dibagi dengan total aset; market to book ratio (MTB) dihitung menggunakan nilai pasar saham perusahaan dibagi dengan nilai buku ekuitas; serta return on asset (ROA) dihitung dengan menggunakan net profit perusahaan dibagi dengan lagged total assets.Dari penjelasan variabel diatas, maka berikut ini model penelitian:

$\mathrm{AA}=\alpha+\beta 1$ SCOREACit $+\beta 2$ REPUT $+\beta 3$ SPECit $+\beta 4$ TENUREit

+ + 5SSCOREACIT $x$ REPUT it + B6SCOREACX SPECit

$+\beta 7$ SCOREACit $x$ TENUREit $+\beta 8$ FSIZEit $+\beta 9$ LEVit $+\beta 10$ MTB

$+\beta 11$ ROAit $+\varepsilon i t$

\section{Hasil Penelitian dan Pembahasan}

Sampel terakhir setelah uji normalitas (uji asumsi klasik) adalah 496 data dengan membuang data yang outlier sebesar 17 badan usaha sehingga uji normalitas menghasilkan sig (2-tailed) sebesar 0,081.

Hasil statistik desktiptif pada Tabel 2 dapat dilihat bahwa variabel AA memiliki nilai mean dari variabel ini sebesar -0,03002. Hal ini menunjukkan bahwa rata-rata perusahaan melakukan earning management dengan mengurangi income. Pada variabel SCOREAC nilai mean dari variabel ini sebesar 11,36. Hal ini menunjukkan bahwa rata-rata perusahaan telah memenuhi persyaratan dalam membentuk komite audit. Pada variabel TENURE memiliki nilai mean dari variabel ini sebesar 4,33, yang berarti bahwa ratarata perusahaan diaudit oleh KAP sebesar 4 tahun. 
Pada variabel SCOREAC $\mathrm{x}$ TENURE memiliki nilai mean sebesar 51,17 yang berarti bahwa rata-rata komite audit dalam suatu perusahaan cenderung mempertahankan KAP. Pada variabel FSIZE memiliki nilai mean pada variabel ini sebesar 12,38. Selain itu, variabel LEV memiliki mean dari variabel ini sebesar 0,53 yang berarti rata-rata perusahaan $53 \%$ asetnya didanai oleh utang.

Pada variabel MTB memiliki nilai mean sebesar 3,06. Hal ini menunjukkan bahwa rata-rata perusahaan memiliki kinerja yang baik yang dinilai oleh pasar.Penilaian pasar sekitar 3 (tiga) kali lebih besar dibandingkan dengan nilai buku perusahaan.Rasio nilai pasar terhadap nilai buku ekuitas yang tinggi umumnya dikarenakan perusahaan tersebut memiliki kinerja yang baik sehingga saham perusahaan banyak diminati publik.

Yang terakhir pada variabel ROA memiliki nilai minimum dan maksimum masing-masing sebesar -1,116 dan 0,4832. Nilai mean dari variabel ini sebesar 0,04 yang berarti bahwa tingkat pengembalian rata-rata aset terhadap laba sebesar 0,04.

Tabel 2

\section{Hasil Statistik Deskriptif}

\begin{tabular}{|l|c|r|r|r|r|}
\hline & N & Minimum & Maximum & \multicolumn{1}{c|}{ Mean } & $\begin{array}{c}\text { Std. } \\
\text { Deviation }\end{array}$ \\
\hline AA & 496 & $-0,8996$ & 0,3943 & $-0,03002$ & 0,11946 \\
\hline SCOREAC & 496 & 4,67 & 66,25 & 11,36 & 7,446 \\
\hline TENURE & 496 & 1 & 11 & 4,33 & 2,522 \\
\hline $\begin{array}{l}\text { SCOREAC x } \\
\text { TENURE }\end{array}$ & 496 & 4,67 & 445,33 & 51,17 & 51,01 \\
\hline FSIZE & 496 & 10,048 & 14,3899 & 12,38 & 0,727 \\
\hline LEV & 496 & 0,0003 & 8,907 & 0,53 & 0,637 \\
\hline MTB & 496 & $-2,695$ & 246,460 & 3,06 & 12,114 \\
\hline ROA & 496 & $-1,116$ & 0,4832 & 0,04 & 0,125 \\
\hline $\begin{array}{l}\text { Valid N } \\
\text { listwise) }\end{array}$ & 496 & & & & \\
\hline
\end{tabular}

\section{Sumber: Hasil Olahan Peneliti}

Pada penelitian ini, perusahaan yang diaudit oleh KAP Non Big Four sebesar $64,5 \%$ dari sampel sedangkan perusahaan yang diaudit oleh KAP Big Four sebesar 35,3\%. Namun, pada perusahaan yang diaudit oleh KAP dengan spesialisasi industri sebesar $38,3 \%$ dari sampel, sedangkan perusahaan yang diaudit oleh KAP non spesialis industri sebesar $61,7 \%$ dari sampel.PadaTabel3menunjukkan hasilkorelasi yang menggunakan PearsonCorrleation.Dapat dilihat bahwa variabel AAmempunyai hubungan signifikan positif terhadap TENURE yang berarti bahwa semakin tinggi abnormal accrual, maka semakin lama auditor mengaudit perusahaan (klien) tersebut.

Untuk variabel SCOREAC memiliki hubungan signifikan positif terhadap REPUT, SPEC, dan TENURE. Hal ini berarti bahwa komite audit cenderung memilih KAP berputasi tinggi, auditor yang terspesialis dalam industri dan cenderung mempertahankan auditor tersebut selama dapat mempertahankan kualitas dari pelaporan keuangan.

Selain itu, pada variabel REPUT memiliki hubungan signifikan positif terhadap SPEC dan TENURE yang berarti bahwa audi-tor yang berputasi tinggi, maka memiliki spesialisasi dalam industri tersebut dan cenderung mempertahankan kliennya.

Kemudian pada variabel SPEC juga memiliki signifikan positif terhadap TENURE, yang berarti bahwa semakin auditor terspesialis dalam industri tertentu, maka semakin lama pula auditor mengaudit perusahaan tersebut.

Variabel TENURE memiliki signifikan positif 0,01 terhadap SCOREAC $\mathrm{x}$ REPUT, yang berarti bahwa semakin efektif komite au-dit dan adanya auditor yang bereputasi tinggi, maka semakin panjang auditor mengaudit pe-rusahaan (klien) tersebut. Variabel TENURE juga memiliki signifikan positif 0,01 terhadap SCOREAC x SPEC, yang berarti bahwa semakin efektif komite audit dan adanya audi-tor spesialisasi industri, maka semakin panjang auditor mengaudit perusahaan (klien) tersebut. 
Tabel 3
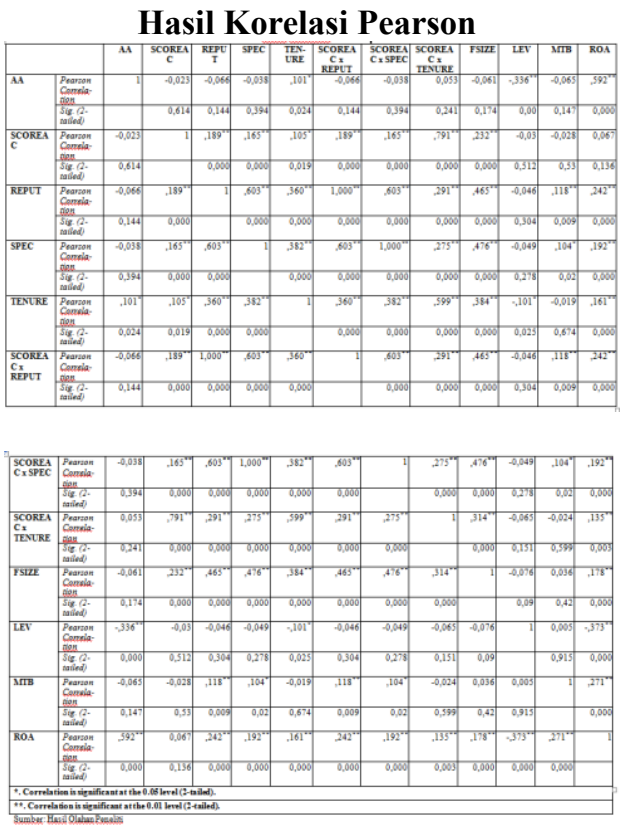

\section{Pembahasan}

Tabel 4

\section{Hasil Pengujian Regresi Linier}

\begin{tabular}{|c|l|c|c|c|}
\hline $\begin{array}{c}\text { Variabel } \\
\text { Dependen }\end{array}$ & Variabel Independen & B & $\mathbf{t}$ & Sig. \\
\hline \multirow{5}{*}{ AA } & (Constant) & 0,21166 & 2,69958 & 0,00718 \\
\cline { 2 - 5 } & SCOREAC & $-0,00085$ & $-0,61976$ & 0,53570 \\
\cline { 2 - 5 } & TENURE & 0,00361 & 1,10739 & 0,26867 \\
\cline { 2 - 5 } & SCOREAC x REPUT & $-0,04104$ & $-3,76707$ & 0,00019 \\
\cline { 2 - 5 } & SCOREAC x SPEC & $-0,00550$ & $-0,51131$ & 0,60936 \\
\cline { 2 - 5 } & SCOREAC x TENURE & 0,00009 & 0,38163 & 0,70290 \\
\cline { 2 - 5 } & FSIZE & $-0,01995$ & $-2,98497$ & 0,00298 \\
\cline { 2 - 5 } & LEV & $-0,01787$ & $-2,65465$ & 0,00820 \\
\cline { 2 - 5 } & MTB & $-0,00216$ & $-6,28347$ & 0,00000 \\
\cline { 2 - 5 } & ROA & 0,63628 & 17,42622 & 0,00000
\end{tabular}

\section{Sumber: Hasil Olahan Peneliti}

Hasil Uji t pada Tabel 4 dapat dilihat bahwa variabel SCOREAC x SPEC tidak memiliki pengaruh signifikan terhadap AA. Hal ini dikarenakan variabel tersebut memiliki tingkat signifkansi sebesar 0,60936. Hal ini mengindikasi bahwa Hipotesis H1 ditolak yang berarti komite audit yang efektif dan auditor spesialisasi industri tidak memiliki pengaruh yang signifikan terhadap earning management. Penelitian ini didukung oleh Chen et al. (2005) mengemukakan bahwa pertemuan komite audit yang tinggi tidak 122 memiliki pengaruh signifikan terhadap penggunaan auditor spesialis industri. Pada hasil uji variabel SCOREAC tidak memiliki pengaruh signifikan terhadap AA. Hal ini berarti bahwa komite audit yang efektif tidak memiliki pengaruh signifikan terhadap earning management. Penelitian ini didukung oleh Prastiti dan Meiranto (2013) mengemukakan pembentukan komite audit hanya didasari untuk pemenuhan regulasi, yang mensyaratkan perusahaan harus memiliki komite audit

Pada analisis regresi linier akan diuji untuk mengetahui apakah variabel REPUT dan SPEC mempengaruhi variabel abnormal accrual. Hal ini disebabkan karena SPSS mengelompokkan variabel REPUT dan SPEC dalam excluded variabel pada saat regresi awal. Hasil dari pengujian regresi pada Tabel 5 terbukti bahwa SPEC tidak memiliki pengaruh terhadap abnormal accrual yang berarti bahwa auditor spesialisasi industri tidak memiliki pengaruh terhadap earning management. Penelitian ini didukung oleh Farida dan Alfin (2014) yang menyatakan bahwa auditor yang memiliki keahlian, pengetahuan, dan pengalaman belum tentu objektif dan independen karena cenderung mempertahankan kliennya.

\section{Tabel 5}

\section{Hasil Pengujian Regresi Linier karena} exluded variabel

\begin{tabular}{|c|l|c|c|c|}
\hline $\begin{array}{c}\text { Variabel } \\
\text { Dependen }\end{array}$ & $\begin{array}{c}\text { Variabel } \\
\text { Independen }\end{array}$ & B & t & Sig. \\
\hline \multirow{6}{*}{} & (Constant) & 0,2111 & 2,6954 & 0,0073 \\
\cline { 2 - 5 } & SCOREAC & $-0,0004$ & $-0,6758$ & 0,4995 \\
\cline { 2 - 5 } & REPUT & $-0,0411$ & $-3,7813$ & 0,0002 \\
\cline { 2 - 5 } & SPEC & $-0,0058$ & $-0,5416$ & 0,5883 \\
\cline { 2 - 5 } & TENURE & 0,0047 & 2,6343 & 0,0087 \\
\cline { 2 - 5 } & FSIZE & $-0,0203$ & $-3,0758$ & 0,0022 \\
\cline { 2 - 5 } & LEV & $-0,0178$ & $-2,6444$ & 0,0084 \\
\cline { 2 - 5 } & MTB & $-0,0022$ & $-6,2801$ & 0,0000 \\
\cline { 2 - 5 } & ROA & 0,6369 & 17,4729 & 0,0000 \\
\hline
\end{tabular}

\section{Sumber: Hasil Olahan Peneliti}

\section{Variabel SCOREAC $\mathrm{x}$ REPUT} terbukti memiliki pengaruh signifikan terhadap AA. Hal ini dikarenakan variabel tersebut memiliki tingkat signifikansi sebesar 0,00019. Hal ini mengindikasi bahwa Hipotesis $\mathrm{H} 2$ diterima yang berarti 
adanya komite audit dan adanya auditor yang memiliki reputasi tinggi, maka dapat menurunkan earning management. Hal ini didukung oleh penelitian Alves (2013) dan Zgarni et al. (2016) yang mengemukakan bahwa efektivitas komite audit dan kualitas audit (auditor Big Four) memiliki pengaruh negatif terhadap earning management. Menurut Alves (2013), mengemukakan bahwa komite audit dan auditor eksternal merupakan bagian dari keseluruhan struktur tata kelola perusahaan sehingga antara komite audit dan auditor eksternal tidak mungkin beroperasi secara independen dalam struktur perusahaan. Oleh karena itu, komite audit dan auditor eksternal memiliki insentif untuk mengeluarkan laporan yang berkualitas tinggi sehingga diharapkan dapat melakukan audit berkualitas tinggi.

Hasil dari pengujian pada Tabel 5 dapat dilihat bahwa variabel REPUT memiliki pengaruh negatif terhadap earning management. Hal ini didukung oleh penelitian sebelumnya Rusmin (2010), yang menyatakan bahwa Big Four auditor memiliki kualitas audit yang baik karena mempunyai jumlah klien yang banyak, sumber daya manusia, teknologi, dan pengalaman yang baik sehingga dengan adanya kualitas audit ini, maka dapat menurunkan earning management. Pada penelitian ini dapat dilihat bahwa pada saat pemilihan KAP, perusahaan akan terlebih dahulu melihat reputasi auditor sebagai kualitas audit dari pada auditor spesialisasi industri. Hal ini disebabkan karena perusahaan dapat mengidentifikasi dengan mudah apakah KAP tersebut memiliki reputasi Big Four atau Non Big Four dibandingkan dengan auditor spesialisasi industri.

Pada variabel SCOREAC $\mathrm{x}$ TENURE tidak memiliki pengaruh signifikan terhadap AA. Hal ini dikarenakan variabel tersebut memiliki tingkat signifikansi sebesar 0,70290. Hal ini mengindikasi bahwa hipotesis H3 ditolak, yang berarti adanya efektif komite audit dan masa audit yang panjang tidak memiliki pengaruh terhadap earning management.Pada penelitian ini, variabel SCOREAC sendiri tidak memiliki pengaruh signifikan terhadap earning management. Menurut Meixner dan Walker (1998) dalam Zgarni et al. (2016) mengemukakan bahwa komite audit yang efektif cenderung mempertahankan auditor. Namun pada penelitian ini, komite audit sendiri belum efektif sehingga memiliki kecenderungan untuk tidak mempertahankan auditor. Selain itu, pada pengujian variabel TENURE sendiri, hasilnya tidak memiliki pengaruh signifikan terhadap AA. Hal ini disebabkan karena variabel tersebut memiliki tingkat signifikansi lebih besar dari 0,05 , yaitu sebesar 0,26867 yang berarti bahwa masa audit yang panjang, maka tidak memiliki pengaruh yang signifikan terhadap earning management. Penelitian ini didukung oleh Jackson et al. (2008), Puspitasari dan Nugrahanti (2016), serta Amijaya dan Prastiwi (2013) yang menyatakan kualitas audit (audit tenure) tidak memiliki pengaruh terhadap manajemen laba. Hal ini disebabkan karena kurangnya kemampuan auditor perusahaan dalam mengidentifikasi manajemen laba yang dilakukan oleh perusahaaan (Amijaya dan Prastiwi, 2013).

\section{Simpulan dan Saran}

Berdasarkan hasil pengujian statistik dan pembahasan yang dilakukan dapat dilihat bahwa secara keseluruhan peran dari komite audit sendiri belum efektif sehingga peran dari komite audit belum mampu memonitor kinerja manajemen. Namun apabila komite audit dimoderasi dengan penggunaan reputasi auditor, maka perannya efektif dalam menurunkan earning management. Sedangkan pada komite audit yang dimoderasi dengan auditor spesialisasi industri, maka perannya belum efektif sehingga tidak memiliki pengaruh dalam menurunkan earning management. Begitu pula dengan komite audit yang dimoderasi 
dengan masa audit yang panjang, maka tidak memiliki pengaruh terhadap earning management. Selanjutnya peneliti memberikan saran yang merupakan keterbatasan pada penelitian ini.Pertama peneliti selanjutnya diharapkan dapat memperluas periode penelitian dengan tidak hanya berfokus pada 2 (dua) periode penelitian.Hal ini dilakukan agar dapat memperoleh hasil yang lebih akurat. Yang kedua, Penelitian selanjutnya diharapkan dapat memperluas pengukuran good corporate governance karena masih banyak pengukuran lain dalam menentukan good corporate governance, seperti karakteristik dari dewan komisaris dan direksi. Ketiga, Peneliti selanjutnya diharapkan dapat memperluas proxy kualitas audit seperti auditor's fees dan independensi auditor.

\section{Daftar Pustaka}

Abbott, L. J. dan Parker, S. 2000. Auditor Selection and Audit Committee Characteristics, Auditing: A Journal of Practice and Theory, Vol. 19 No. 2, pp. 47-66.

Abbott, L. J. dan Parker, S. 2000. The Effect of Audit Committee Activity and Independence on Corporate Fraud, Vol. 26 No. 11, pp. 47-66.

Alves, S. 2013. The impact of audit committee existence and external audit on earnings management: Evidence from Portugal. Journal of Financial Reporting \& Accounting, Vol. 11 Issue: 2, pp.143-165

Amijaya, M.D dan Prastiwi.2013. Pengaruh Kualitas Audit Terhadap Manajemen Laba.Diponegoro Journal of Accounting, Vol.2, Nomor 3.

Bartov, E., Gul, F.A., dan Tsui, J.S.L. 2000.Discretionary-accruals models and audit qualifications. Journal of Accounting and
Economics, Vol. 30 No. 3, pp. 421-52.

Becker, C.L., DeFond, M.L., Jiambalvo, J. dan Subramanyam, K.R. 1998. The effect of audit quality on earnings management. Contemporary Accounting Research, Vol. 15 No. 1, pp. 1-24.

Beneish, M.D. 2001.Earnings management: a perspective", Managerial Finance, Vol. 27 No. 12, pp. 3-17.

Bronson, S.N., Carcello, J.V., Hollingswoth, C.W., Neal, T.L., 2009. Are Fully Independent Audit Committees Really Necessary? Journal Public Policy, pp 265-280.

Chen, Y.M., Moroney., dan Houghyon, K. 2005. Audit Committee Composition and The Use of Industry Specialist Audit Firm. Journal Accounting and Finance, pp 217-239

Christiani, I dan Nurgahanti, Y. W. 2014.Pengaruh Kualitas Audit Terhadap Manajemen Laba.Jurnal Akuntansi dan Keuangan, Vol.16, No.1.

Dechow, P.M. and Skinner, D.J. 2000. Earnings reconciling the views of accounting academics, practitioners, and regulators. Accounting Horizons, Vol. 14 No. 2, pp. 235-250.

Defond, M.L dan Francis, J.R. 2005 Audit Research After Sarbanes-Oxley. Auditing: A Journal Of Practice \& Theory, Vol 24, pp. 5-30.

Farida,I dan Alfin, M. 2014. Pengaruh Kualitas Audit dan Ukuran Komite Audt Terhadap Manajemen Laba.Jurnal Bisnis dan Manajemen Laba, Vol. 2, No. 2, Hal 132-143.

Garg, A.G. (2007), Influence of board size and independence on firm performance: a study of Indian companies. ViKALPA, Vol. 32 No. 3, pp. 39-60. 
http://bisnis.liputan6.com/read/2031867/enr on-skandal-besar-perusahaanenergi-yang-cekik-investor, diakses tanggal 10 Mei 2017.

http://www.ecgi.org/codes/documents/indo nesia_cg_2006_id.pdf, diakses tanggal 4 Juni 2017

http://www.fcgi.or.id/corporategovernance/about-good-corporategovernance.html, diakses tanggal 4 Juni 2017

https://m.tempo.co/read/news/2017/02/11/0 $87845604 /$ mitra-ernst-young indonesia-didenda-rp-13-miliar-dias, diakses tanggal 10 Mei 2017.

Inaam, Z. dan Khamoussi, H. 2016.Audit Committee Effectiveness, Audit Quality, and Earning Management: A Meta-Analysis. International Journal of Law and Management, Vol.58 Issue: 2, pp 179-196.

Jackson, A.B., Moldrich,A., Roebuck. P. 2008.Mandatory Audit Firm Rotation and Audit Quality. Managerial; Auditing Journal Vol. 23, No.5, pp 420-437.

Klein, A. 2002.Audit committee, board of director characteristics, and earnings management, Journal of Accounting and Economics, Vol. 33 No. 3, pp. 375-400.

Khlif, H dan Samaha,K. 2016. Audit committee activity and internal control quality in Egypt: Does external auditor's size matter? Managerial Auditing Journal, Vol. 31 Issue: 3, pp.269-289.

Leventis, S. dan Dimitropoulos, P. 2012.The Role of Corporate Governance in Earning Management: Experience from US Banks. Journal of Applied Accounting Research, Vol. 13 Issue: 2, pp. 161-177.

Lidiawati, N dan Asyik, N. F. 2016. Pengaruh Kualitas Audit, Komite Audit, Kepemilikan Institusional, Ukuran Perusahaan Terhadap
Manajemen Laba. Jurnal Ilmu dan Riset Akuntansi: Volume 5.

Myers, J.N., Myers, L.A., dan Omer. T.C. 2003.Exploring The Term of The Auditor-Client Relationship and Quality of Earnings: A Case For Mandatory Audit Rotation? The Accounting Review, Vol.78, No. 3, pp 779-799.

Nor, Mohamad, M.N., Shafie, R., dan Hussin, Wan, N.W. 2010.Corporate Governance and Audit Report Lag In Malaysia. Asian Academy of Journal of Accounting and Finance, Vol.6, No.2, pp 57-84.

Prastiti, A dan Meriranto, W. Pengaruh Karakteristik Dewan Komisaris dan Komite Audit Terhadap Manajemen Laba. Diponegoro Journal Of Accounting, Vol 2, Nomor 4.

Puspitasti, A. dan Nugrahanti, Y.W. 2016. Pengaruh Hubungan Politik, Ukuran KAP, dan Audit Tenure Terhadap Manajemen Laba Rill. Jurnal Akuntansi dan Keuangan, Vol. 18, No.2, pp 27-43.

Rusmin, R. 2010. Auditor Quality and Earning Management: Singapore Evidence. Managaerial Auditing Journal, Vol. 25 Issue: 7, pp.618638

Rahmat, M.M., Iskandar, T.M., dan Saleh, N.M. 2009. Audit Committee Characteristics in Financially Distress and Non- Distressed Company. Managerial Auditing Journal, Vol 24 No.7. pp. 624-629.

Scott, William R. 2015. Financial Accounting Theory. 7 th ed. Pearson.

Sun, J dan Liu, G., 2012.Auditor industry specialization, board governance, and earnings management. Managerial Auditing Journal, Vol. 28 Issue: 1, pp.45-64

Taktak, N.B., dan Mbarki, I. 2014. Board characteristics, external auditing 
Jurnal Akuntansi Maranathaø Volume 11 Nomor 1, Mei 2019 :115 - 126

quality and earnings management: Evidence from the Tunisian bank. Journal of Accounting in Emerging Economies, Vol. 4 Issue: 1, pp.79-96

Zgarni, I., HLIOUI, K., dan Zehri, F. 2016. Effective Audit Committee, Audit Quality, and Earning Management: Evidence From Tunisia, Journal of Accounting in Emerging Economies, Vol. 6 Issue: 1, pp. 138-155. 